\title{
On Problems and Solutions to College English Translation Teaching
}

\author{
Lijing Diao* \\ * English Department, Cangzhou Normal University, Cangzhou 061001, Hebei, China
}

\begin{abstract}
This paper analyzes the inadequacies of College English Translation Teaching from five aspects: teaching syllabus, teaching evaluation, teaching content, teaching method and teaching staff construction, and makes a number of suggestions to solve the problems accordingly.
\end{abstract}

Keywords: English translation teaching; problems; solutions

\section{Introduction}

Translation Teaching is an important part of college English teaching and a main approach to train translators. However, nowadays there are a lot of deficiencies in college English translation teaching which restrict the further development of the College English Translation Teaching and hinder the cultivation of foreign language translators.

\section{Inadequacies of College English Translation Teaching}

\subsection{Teaching is lack of overall plan- ning}

College English Syllabus 2004 makes demands for non-English major students at different levels to achieve the translation ability, but its request is not clear and specific enough. It doesn't formulate an overall teaching plan or specify the teaching contents for different levels of students, therefore many problems arise such as teaching content linking between different levels of translation teaching.

\subsection{Teaching Evaluation is lack of di- versity}

Testing is an important part of teaching. CET -4 and CET- 6 are the major means of testing on college English teaching. However, before 2006 there was only question type in CET-4, namely, translate the underlined sentences from English to Chinese. Afterwards the question type is changed into transition from Chinese to English, still the single kind of question and still a disguised test on vocabulary, grammar and phrase structure. In this test the questions are difficult to cover the knowledge and skills needed to examine and difficult to link up with corresponding teaching stages effectively.

\subsection{Teaching content is not systemic and lack of integrity}

College English textbooks used at college do not have comprehensive introduction to translation theory and skills, but only a small amount of translation exercises. Currently there is almost not a translation textbook compiled specifically for nationwide non-foreign language students on the market. Due to the Syllabus restrictions and constantly updated college English teaching materials, textbook knowledge points are used repeatedly and exercises are not systematic. It is difficult to arouse the 
students' enthusiasm and to increase teaching quality.

\subsection{A single teaching method domi- nates the college English transla- tion teaching}

Over a long period of time translation pedagogy is error correction pedagogy. In this model teachers are the center and error correction is the means of teaching, so the knowledge is disseminated one from teachers to students and reference answers are regarded as the ultimate goal of teaching. This indoctrination teaching method can not guarantee that the principal role of the students. It is lack of cultivation of students' innovative spirit, stifles the enthusiasm of students learning translation and hinders the improvement of the quality of the translation teaching in China. In addition, there are only nine papers on College English Translation Teaching pedagogy in the literature of the past 20 years $^{[1]}$. College English translation teaching method research is clearly insufficient.

\subsection{The construction of teaching staff needs to be strengthened}

Currently teachers engaged in the translation teaching can not meet the demand for college English translation teaching whether in the quantity or quality. As Murray said, compared to a decade ago translation teachers' ages and title structure have been becoming more and more reasonable, but the majority of teachers are still lack of strictly vocational training and academic training $^{[2]}$.
3. Some suggestions to improve the quality of college English translation teaching

\subsection{Improve the Syllabus require- ments for translation ability and further clarify the requirements of the translation materials and skills.}

We need toe establish correct teaching and guiding ideology and find the right positioning for College English Translation Teaching. Colleges and universities can develop English translation syllabus suitable for their own actual situation and establish scientific and reasonable curriculum system so as to provide a starting point a practical basis for translation teaching reform. Meanwhile, all colleges and universities should attach importance to the cultivation of the translation ability. Put equal emphasis on translation, listening, speaking, reading and writing teaching to nurture students' creative thinking ability and English-Chinese bilingual skills.

\subsection{Emphasis on the evaluation of the students' ability to translate.}

Any test will have some counteractive effect on teaching. If an examination is able to fully test the candidate's level of translation and to promote translation teaching, it is undoubtedly promote the development of the College English Translation Teaching. The form and content of the test should be diversified. The kinds of questions need to be designed carefully and give full consideration to the validity of the translation test. The content of the test should be targeted. Translation test must be used as a standing item on college English teaching level detection and becomes the extrinsic motivation to 
encourage students to value and improve their practical translation ability.

\subsection{Compile college English transla- tion teaching materials in accord- ance with the requirements of the times and society.}

On one hand, new college English teaching materials should strengthen the importance of translation theory and increase more translation resources so that teachers and students can take full advantage of the material resources. On the other hand, the translation textbooks for non-English major students should be compiled unitarily. The teaching materials should reflect the current economic and cultural development and new translation teaching concepts. It ought to be combined with the majors of the students and have fun and practicality to help develop students' thinking and innovation capability ${ }^{[3]}$.

\subsection{Improve teaching methods and optimize teaching organization.}

College English Translation Teaching should abandon the teacher-centered model and promote students to understand translation skills and strategies in the process of translation practice emphasizing the teaching interaction and cooperation. It should be learner-centered and give full consideration to the initiation of the learners. Teaching has rules but not certain rules. The translation workshop proposed by Xiao Hong is a good exploration ${ }^{[4]}$. Moreover, we should take full advantage of modern educational technology and new research results in translation teaching field. Network resources and the application of corpusaided translation teaching will have a great effect on the development of the College English Translation Teaching.

\subsection{Strengthen the teaching staff con- struction and improve teachers' professional quality.}

Translation is a highly integrated discipline and requires the teachers to have a solid English foundation and a wealth of background knowledge. Therefore, it is very important to strengthen the post-employment education of the teachers and to promote their literacy translation theory, practical ability and teaching standard in order to meet the developing needs of the college English translation teaching. In-service education, orientation training and to have translation teaching academic lectures are all effective methods.

\section{Conclusion}

As long as we find the problems of College English Translation Teaching, explore and research carefully and put the results into teaching practice, we will be able to make the translation teaching go up to a new level and cultivate excellent translation talents for the society.

\section{References}

[1] Xioawei Chen. Several Aspects Needed to Strengthen Urgently in Terms of Grade 8. Chinese Translation. 2002,1: 45-47.

[2] Lei Mu. The Role of Translation Theory in Translation Teaching. Journal of Sichuan International Studies University. 2005,1: 18-19.

[3] Zhonglian Huang. The Indispensable Kinds of Questions in CET-4. Foreign Language World. 1997,1: 71-74.

[4] Hong Xiao. Translation Workshop in Translation Teaching. Journal of Sichuan International Studies University. 2005,1:23-25. 